\title{
Rancang Bangun Alat Pemantau Infus Menggunkan Modul 433 Mhz dan Sensor Load Cell Berbasis Arduino Uno
}

\section{Lilis T. Y. Tampubolon*1, Indra Gunawan ${ }^{2}$, Zulaini Masruro Nasution ${ }^{3}$, Sumarno ${ }^{4}$, Heru Satria Tambunan $^{5}$}

1,2,3,4,5 Teknik Informatika, STIKOM Tunas Bangsa Pematangsiantar, Indonesia

Email: ${ }^{1}$ listabing@gmail.com, ${ }^{2}$ Indra@ amiktunasbangsa.ac.id, ${ }^{3}$ zulaini@amiktunasbangsa.ac.id, ${ }^{4}$ sumarno@amiktunasbangsa.ac.id, ${ }^{5}$ heru@amiktunasbangsa.ac.id.

\begin{abstract}
Abstrak
Kesalahan dalam pemberian cairan infus dapat berakibat buruk kepada pasien, juga apabila terjadi masalah seperti penyumbatan atau kehabisan cairan jika tidak segera ditangani akan berbahaya bagi pasien. Infus yang ada saat ini penggunaannya masih secara manual dimana kesalahan seperti tersebut masih sering terjadi, oleh karena itu penulis membuat suatu infus yang dapat bekerja secara otomatis. Pada penelitian ini, penulis membuat suatu infus otomatis yang dapat memonitoring infus secara berkala, dimana dokter atau suster hanya tinggal memantau di tempat mereka berjaga. Sensor yang digunakan pada alat ini yaitu Modul RF $433 \mathrm{Mhz}$ dan sensor berat (load cell) dengan bantuan Modul HX-711. Pada penelitian ini digunakan mikrokontroller Arduino Uno sebagai data untuk monitoring infus jarak jauh. LCD, buzzer dan LED digunakan sebagai output yang memudahkan dokter atau suster dalam memantau situasi infus. Hasil dari penelitian ini dimulai dari sensor berat dan Modul RF 433 Mhz yang mengirim data ke Arduino lalu kemudian di dalam Arduino data di proses sebelum mengaktifkan output berupa lampu LED untuk pemberitahuan kondisi infus telah habis atau infus sedang berhenti. Rancangan alat pemantau infus yang dibuat secara keseluruhan dapat bekerja dengan baik dan memungkinkan dapat diterapkan di rumah sakit.
\end{abstract}

Kata kunci: Arduino Uno, Infus, Modul RF 433 Mhz, Sensor Berat (Load Cell)

\begin{abstract}
Errors in giving intravenous fluids can be bad for the patient, also if there are problems such as blockages or run out of fluid if not treated immediately will be dangerous for patients. The current infusion is still manually used where errors like that still occur frequently, therefore the authors make an infusion that can work automatically.In this study, the authors make an automatic infusion that can monitor the infusion periodically, where the doctor or nurse only needs to monitor where they are on guard. The sensor used in this tool is the 433 Mhz RF Module and the weight sensor (load cell) with the help of the HX-711 Module. In this study, the Arduino Uno microcontroller was used as data for remote infusion monitoring. LCD, buzzer and LED are used as outputs that make it easier for doctors or nurses to monitor the infusion situation. The results of this study start from the weight sensor and the $433 \mathrm{Mhz}$ RF Module which sends data to the Arduino and then in the Arduino the data is processed before activating the output in the form of an LED light for notification of the condition that the infusion has run out or the infusion is stopping. The design of infusion monitoring devices that are made as a whole can work welland allow it to be implemented in hospitals.
\end{abstract}

Keywords:. Arduino Uno, Infusion, RF Module $433 \mathrm{Mhz}$, Weight Sensor (Load Cell)

\section{PENDAHULUAN}

Dalam dunia kesehatan, infus adalah alat medis yang digunakan pada kondisi tertentu untuk memberikan cairan kepada tubuh pasien secara periodik. Kekentalan dalam cairan infus sangat beragam dan masuknya kedalam tubuh juga berbeda kapasitasnya. Untuk pasien yang sedang kritis diperlukan obat-obatan yang kepekatannya tinggi, sedangkan untuk pasien yang tidak terlalu kritis diperlukan cairan pembantu metabolisme. Cairan atau obat-obatan yang dimasukkan menggunakan infus langsung melalui pembuluh darah vena. 
Kita ketahui beberapa rumah sakit pemantauan tetesan infus masih dilakukan secara manual, sehingga membutuhkan perhatian dari perawat rumah sakit untuk meninjau pasien tiap kamar dalam waktu yang telah diperkirakan. Botol infus yang sudah kosong harus segera ditukar dengan yang baru. Ketika infus habis maka pasien dan keluarganya harus segera memberitahukan pada perawat yang dinas dengan menekan tombol agar perawat segera mengganti botol cairan infus dengan yang baru. Perawat harus memeriksa kondisi infus dalam waktu yang telah ditentukan sebelumnya, sehingga perawat harus berulang-ulang memeriksa kondisi pasien supaya tidak terjadi keterlambatan ketika mengganti cairan infus pasien, keluarga pasien harus selalu memantau agar dapat memastikan pasien tetap terjaga, ini juga dapat menjadi imbas buruk bagi keluarga yang menjaga pasien tanpa istirahat yang dimana bisa menyebabkan jatuh sakit karena kurang istirahat.

Berdasarkan uraian di atas penulis ingin merancang sebuah sistem yang dapat memudahkan pekerjaan perawat dalam memantau proses infus. Dengan menggunakan sensor berat (load cell) untuk mengetahui cairan dibotol infus akan habis dan Modul RF 433 Mhz sebagai indikator pemberitahu tanpa kabel. Serta penggunaan led dan buzzer yang dipasang di Nurses Station (NS) atau ruang perawat sebagai indikator penerima pemberitahuan pada saat cairan dibotol infus akan habis. Ketika cairan infus akan habis maka modul RF $433 \mathrm{Mhz}$ akan memberikan sinyal peringatan yang akan menghidupkan led dan buzzer sebagai notifikasi berada di Nurses Station atau ruangan perawat.

\subsection{Arduino}

Arduino Uno adalah papan mikrokontroler berdasarkan ATmega328 (datasheet). Dalam bahasa Itali "Uno" berarti satu, maka jangan heran jika peluncuran Arduino 1.0 diberi nama Uno. Arduino ini berisi semua yang diperlukan untuk mendukung mikrokontroler, untuk mengaktifkan cukup menghubungkannya ke komputer dengan kabel USB dengan adaptor AC-DC atau baterai.Arduino merupakan kit elektronik atau papan rangkaian elektronik open source yang di dalamnya terdapat komponen utama yaitu sebuah chip mikrokontroler dengan jenis AVR dari perusahaan Atmel (Rumopa \& Luther Mappadang, 2015).

Arduino berbasis mikrocontroller ATMega yang dirilis oleh Atmel dan banyak di kembangkan didunia, berikut ini merupakan jenis-jenis dari Arduino:

1. Arduino Uno

2. Arduino Duemilanove

3. Arduino Leonardo

4. Arduino Mega2560

5. Arduino Intel Galileo

6. Arduino Pro Micro AT

7. Arduino Nano R3

8. Arduino Mini Atmega

9. Arduino Mega ADK

Gambar dari arduino bisa dilihat pada Gambar 1 di bawah ini:

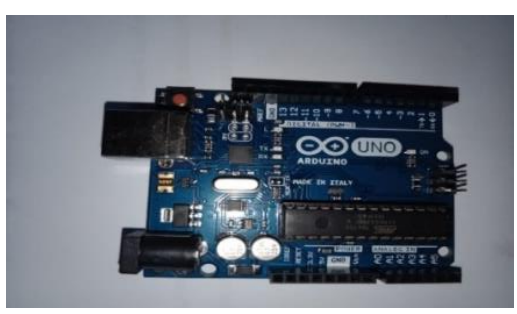

Gambar 1. Arduino

Untuk lebih jelasnya dapat di lihat dari spesifikasi Arduino Uno pada Tabel 1 berikut: 
Tabel 1. Spesifikasi Arduino Uno

\begin{tabular}{ccc}
\hline No. & Mikrokontroler & Atmega 328 \\
\hline 1. & Tegangan Operasi & $5 \mathrm{~V}$ \\
2. & Tegangan Input & (disarankan) $7-12 \mathrm{~V}$ \\
3. & Batas Tegangan Input & $6-2 \mathrm{OV}$ \\
4. & Pin Digital I/O & 14 (di mana pin 6 output PWM) \\
5. & Pin Analog Input & 6 \\
6. & Arus DC per I/O Pin & $40 \mathrm{~mA}$ \\
7. & Arus DC untuk pin & $3.3 \mathrm{~V} 50 \mathrm{~mA}$ \\
8. & Flash Memory & KB (ATmega328), di mana $0,5 \mathrm{~KB}$ \\
& digunakan olehbootloader \\
9. & SRAM & $2 \mathrm{~KB}($ Atmega328) \\
10. & EEPROM & $1 \mathrm{~KB}($ Atmega328) \\
11. & Clock & $16 \mathrm{MHz}$ \\
\hline
\end{tabular}

\subsection{Infus}

Infus adalah fasilitas untuk pasien yang diberikan oleh rumah sakit. Alat infus ini digunakan untuk memberikan cairan ataupun obat pasien. Pada beberapa rumah sakit, alat infus masih dipasang secara manual. Sehingga masih membutuhkan ekstra perhatian dari perawat rumah sakit untuk sering meninjau pasien tiap kamar (Hartanti, 2016).

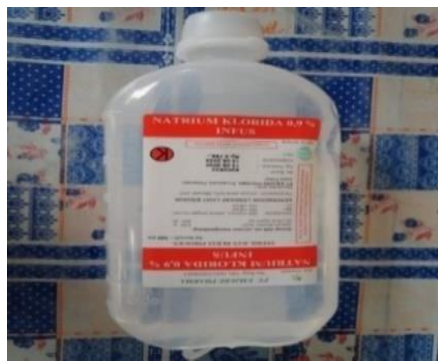

Gambar 2. Infus

Pada Gambar 2 dapat kita lihat botol infus yang didalamnya terdapat cairan obat yang disalurkan ke dalam tubuh.

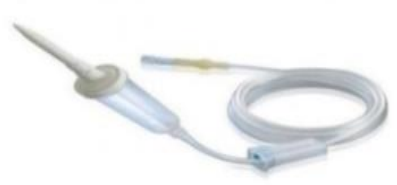

Gambar 3. Selang Infus

\subsection{Sensor}

Sensor adalah alat yang mampu menangkap fenomena fisika atau kimia kemudian mengubah menjadi sinyal elektrik baik arus listrik ataupun tegangan. Fenomena fisik yang mampu menstimulus sensor untuk menghasilkan sinyal elektrik meliputi temperatur, tekanan, gaya, medan magnet cahaya, pergerakan dan sebagainya (Adha et al., 2015). Sensor yang akan diperlukan dapat membantu penulis ketika merancang alat pemantau infus berbasis Arduino Uno agar bekerja dengan baik dalam memantau infus yang berhenti dan habis. 
Sensor Berat (load cell) merupakan sensor yang dirancang untuk mendeteksi tekanan atau berat sebuah beban, sensor load cell umumnya digunakan sebagai komponen utama pada sistem timbangan digital, dapat diaplikasikan pada jembatan timbangan yang berfungsi untuk menimbang berat dari truk pengangkut bahan baku, pengukuran yang dilakukan oleh load cell menggunakan prinsip tekanan tersebut (Desmitha et al., 2019).

Sensor ini akan digunakan untuk menimbang berat pada infus agar infus dapat terdeteksi ketika habis. Pada Gambar 4 di bawah ini dapat kita lihat bentuk fisik dari sensor berat (load cell).

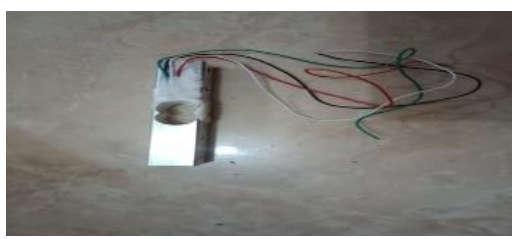

Gamabar 4. Sensor Berat

\subsection{Soket USB}

Soket USB merupakan soket yang berupa kabel USB yang akan di sambungkan ke laptop atau komputer. Dimana nantinya, kabel USB sebagai berfunsi untuk mengirimkan program ke Arduino dan juga sebagai port komunikasi serial (Iman et al., 2021).

\subsection{Modul RF $433 \mathrm{Mhz}$}

RF Modul (modul frekuensi radio) adalah perangkat elektronik yang digunakan untuk mengirim atau menerima sinyal radio antara dua perangkat. RF Modul yang paling sering digunakan untuk aplikasi pembuka garasi, sistem alarm nirkabel, remote kontrol, aplikasi sensor pintar, dan sistem otomasi rumah nirkabel (Rohman et al., 2017).

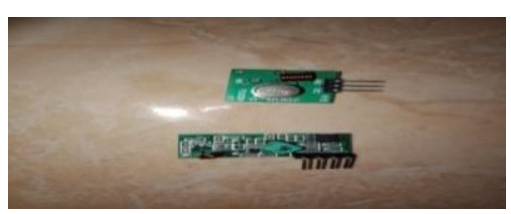

Gambar 5. Modul RF $433 \mathrm{Mhz}$

\subsection{Modul $H X-711$}

Modul HX-711 adalah modul yang memudahkan dalam membaca load cell dalam pengukuran berat. Modul ini berfungsi untuk menguatkan sinyal keluaran dari sensor dan mengonversi data analog menjadi data digital (Desmitha et al., 2019).

Dengan menghubungkannya ke Arduino Uno, kita dapat membaca perubahan resistansi dari load cell. Pada saat proses kalibrasi kita akan menerima pengukuran berat dengan akurat yang tinggi. Pada Gambar 6 di bawah ini dapat kita lihat bentuk fisik dari Modul HX-711.

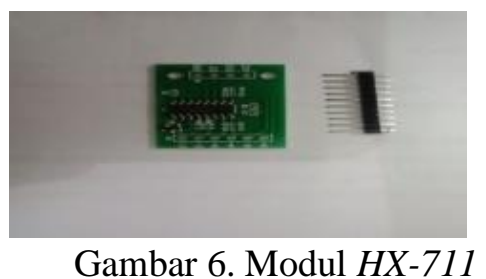

\subsection{Buzzer}

Buzzer adalah sebuah komponen elektronika yang dapat mengubah sinyal listrik menjadi getaran suara. Pada umumnya, buzzer adalah sebuah perangkat audio ini sering digunakan pada 
rangkaian anti maling, pada jam tangan, peringatan mundur pada truk dan perangkat peringatan bahaya lainnya (Bernandus et al., 2019).

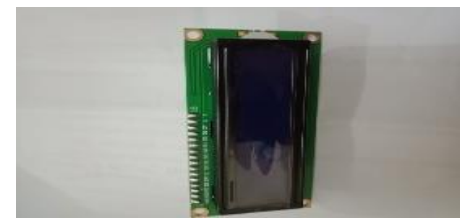

Gambar 7. Buzzer

\subsection{LCD (Liquid Crystal Display)}

Untuk memudahkan penulis dalam melakukukan pengamatan, uji coba dan simulsai untuk membaca keadaan cuaca serta pergerakkan Motor DC, maka penulis menggunakan sebuah alat LCD (Liquid Crystal display). LCD (Liquid Crystal Display) digunakan untuk menampilkan informasi elektronik seperti teks (huruf), angka atau simbol (Siswanto \& Winardi, 2015).

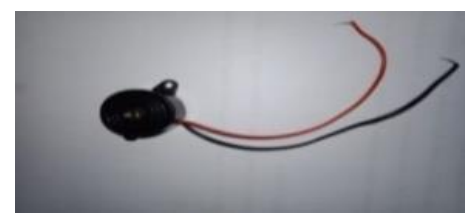

Gambar 8. LCD (Liquid Crystal Display

\section{METODE PENELITIAN}

Metodologi yang digunakan dalam perancangan dan pengembangan sistem yang dibuat meliputi dua metode yaitu metode pengumpulan data dan metode pengembangan sistem.

\subsection{Perancangan Penelitian}

Pada perancangan penelitian ini dimulai dari pengambilan data yang kemudian diolah sehingga menghasilkan output sebagai berikut:

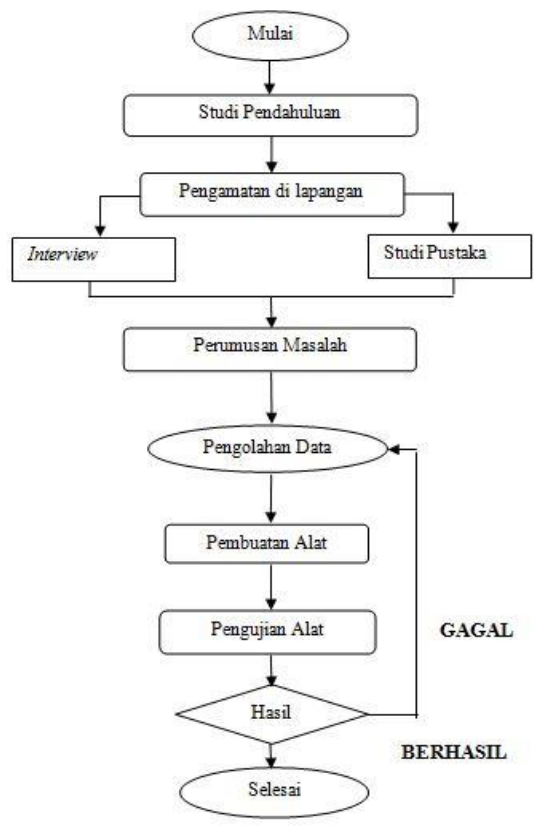

Gambar. 9 Flowchart Penelitian 


\subsection{Alat Analisis Data}

Dalam perancangan alat pemantau infus menggunakan Modul RF $433 \mathrm{Mhz}$ dan sensor berat (load cell) berbasis Arduino Uno, maka diperlukan data atau teknik analisis data. Di dalam analisis data peneliti menggunakan teknik analisis deskriptif yang penyajian datanya dalam bentuk tabel yang terdiri dari perangkat keras (hardware) dan perangkat lunak (software).

\subsection{Instrumen Penelitian}

Adapun instrumen dalam penelitian yang digunakan untuk pengujian kinerja instrumen alat pemantau infus berbasis microcontroller Arduino Uno diantaranya adalah:

1. Penguji ahli dalam bidang medis berfungsi menilai alat ini layak diuji coba atau direvisi kembali.

2. Penguji ahli bidang elektro berfungsi untuk menilai alat ini dari tinjauan ilmu elektro.

\subsection{Diagram Aktifitas Kerja Penelitian}

Untuk menghidupkan rangkaian Arduino diperlukan sumber listrik. Tetapi jika arus listrik mati Arduino tetap dapat hidup melalui kabel USB yang bersumber pada baterai, powerbank atau sejenisnya. Sedangkan rekomendasi tegangan Arduino berkisaran 6 VCD sampai dengan 12 VCD. Kemudian input didapat dari sensor berat dan Modul RF 433 Mhz yang mengirim data ke Arduino lalu kemudian di dalam Arduino data di proses sebelum mengaktifkan output berupa lampu LED untuk pemberitahuan kondisi infus telah habis atau infus sedang berhenti.

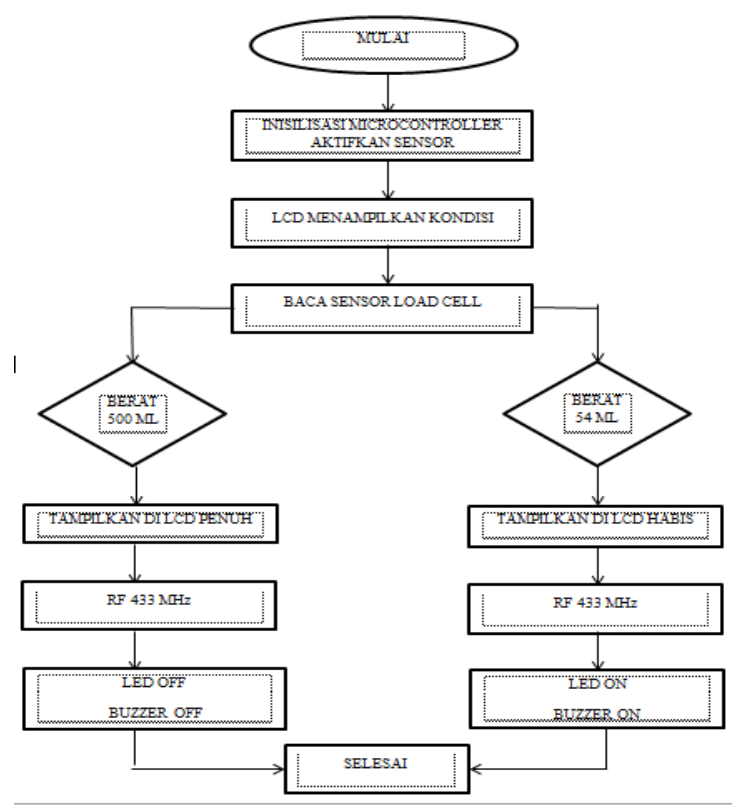

Gambar 10. Alur Kontrol Infus Berbasis Arduino

Keterangan Gambar 10 pada saat Arduino Uno dihidupkan, yang pertama dilakukan adalah inisialisasi pada sensor, kemudian setelah itu arduino akan melakukan peroses pembacaan sensor secara bersamaan.

1. Mulai, menghidupkan alat.

2. Baca sensor, sensor menyala kemudian membaca kondisi infus.

3. Tampil di LCD, hasil yang di dapat dari sensor kemudian di tampilkan di LCD.

4. Sensor Berat (load cell), sensor ini mengukur berat pada infus $500 \mathrm{ml}$ maka buzzer dan led off, ketika berat infus ada di kisaran $20 \mathrm{ml}$ maka buzzer dan led on.

5. Modul RF $433 \mathrm{Mhz}$, alat ini mendeteksi kondisi habis atau masih berisi, ketika normal buzzer dan led off, ketika infus habis buzzer dan led on. 


\subsection{Pemodelan Metode}

Pada pemodelan atau perancangan sistem dijelaskan mengenai komponen yang digunakan dalam pembuatan alat pemantau infus.

a. Perancangan Mekanik/ Pemodelan

Pada perancangan mekanik terdiri dari perencanaan desain mekanik perangkat keras yang mendukung kinerja. Pembuatan perangkat mekanik terdiri dari perencanaan desain mekanis yang mendukung kinerja alat dan berkarakter sesuai pada kondisi sesungguhnya. Perencanaan ini terdiri dari pengaturan peletakan posisi Infus, LCD, Arduino Uno, Sensor berat (Load Cell), Modul RF 433 Mhz, buzzer dan LED dilihat pada Gambar 11 di bawah ini.

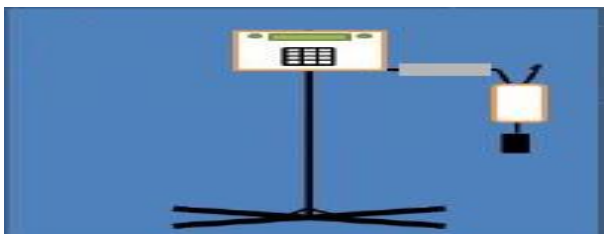

Gambar 11. Rangkaian Mekanik

b. Diagram Blok

Berikut adalah Blok Diagram Sistem Pemantau Infus.

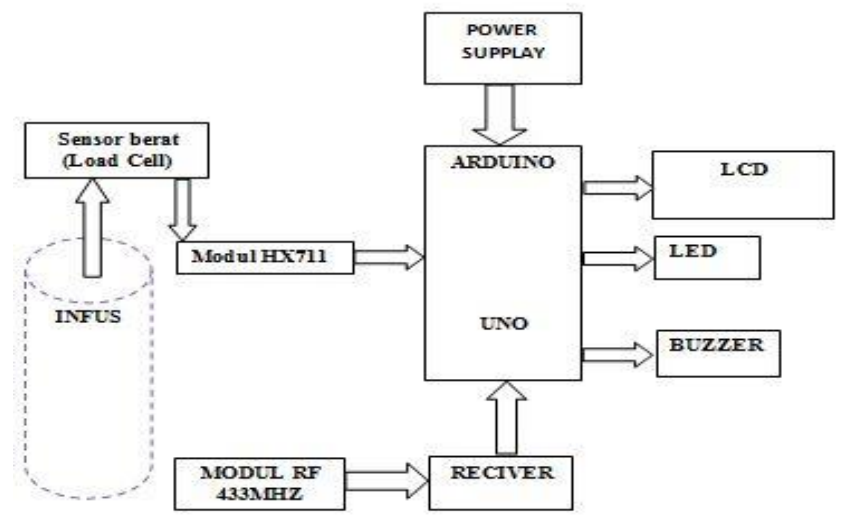

Gambar 12. Diagram Blok

Dari Gambar 12 di atas dapat diuraikan fungsi tiap blok rangkaian sebagai berikut:

a. Blok Adaptor merupakan bagian pada perancangan alat yang berfungsi sebagai pemberi tegangan atau catu daya untuk mengaktifkan seluruh komponen. Sumber tegangan untuk alat ini adalah Adaptor 5-12 V untuk mengaktifkan Arduino Uno serta perangkat lainnya.

b. Blok Sensor Berat (load cell) yang berfungsi sebagai input pin analog dari board Arduino Uno untuk mengukur berat infus

c. Blok Modul HX-711 juga berfungsi sebagai inputan pin analog dari board Arduino Uno untuk membantu sensor berat (load cell) dalam membaca load cell dalam pengukuran berat.

d. Blok Modul RF $433 \mathrm{Mhz}$ berfungsi sebagai input pin analog dari board Arduino Uno untuk memberikan informasi keadaan infus tanpa kabel ke ruangan perawat

e. Blok Arduino Uno yang berfungsi untuk mengolah data dari hasil deteksi sensor air, dan sensor cahaya dari lingkungan luar.

f. Blok LCD yang berfungsi untuk menampilkan hasil yang di dapat dari sesnsor yang di kelola oleh Arduino Uno.

g. Blok Buzzer yang berfungsi sebagai alarm untuk pemberitahuan apabila infus habis.

h. Blok LED yang berfungsi untuk penanda ruangan. 


\section{HASIL DAN PEMBAHASAN}

Tujuan dari pengujian dan pembahasan sistem ini adalah untuk mengetahui kinerja dari alat satu persatu maupun secara keseluruhan sistem. Pengujian kinerja alat dan keseluruhan sistem didasarkan pada perancangan sistem. Hasil dari pengujian ini akan digunakan untuk dasar menentukan kesimpulan dan kekurangan dari sistem agar sesuai dengan perancangan sistem.

Pengujian yang akan dilakukan adalah pengujian masing-masing blok rangkaian. Setelah semua blok rangkaian akan diuji, pengujian berikutnya adalah pengujian keseluruhan sistem. Pengujian pada keseluruhan sistem ini berfungsi untuk mengetahui bagaimana kinerja dan tingkat keberhasilan dari sistem tersebut.

Pengujian yang dilakukan adalah sebagai berikut :

1. Pengujian PowerBank Shiled.

2. Pengujian Load Cell.

3. Pengujian LCD.

4. Pengujian LED.

5. Pengujian Module RF $433 \mathrm{Mhz}$.

6. Pengujian keseluruhan.

\subsection{Pengujian LCD}

Pada pengujian LCD bertujuan untuk mengetahui Arduino ini bisa menampilkan karakter pada LCD dan menampilkan maksimal 16 karakter pada LCD tersebut. Berikut ini adalah hasil pengujian LCD melalui Arduino Uno sebelum merancang keseluruhan alat .

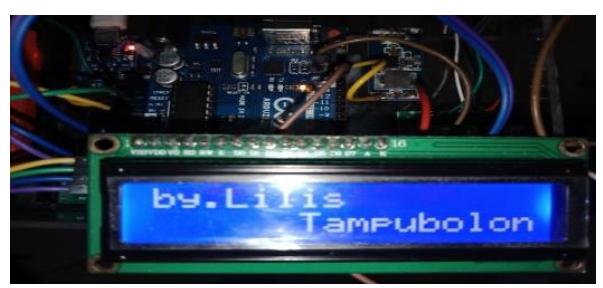

Gambar 13. Hasil Pengujian LCD

Dari rangkaian di atas, arduino telah digubungkan pada SCL pada LCD ke pin A5 Arduino, SDA pada LCD ke A4 Arduino, VCC pada LCD ke 5V Arduino, dan Menghubungkan GND pada LCD ke GND Arduino.

\subsection{Pengujian Pada Powerbank Shiled}

Pada pengujian Powerbank Shiled ini dilakukan dengan menghubungkan Powerbank Shiled ke Arduino Uno.

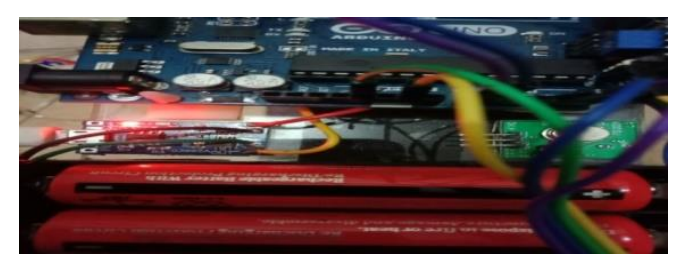

Gambar 14. Hasil Pengujian Powerbank Shiled

Dari rangkaian di atas, Powerbank Shiled telah dihubungkan ke Arduino Uno, B+ pada TP4056 ke B+ pada baterai, B- pada TP4056 ke B- pada baterai, OUT + pada TP4056 ke IN + pada STEP UP 5V, dan OUT - pada TP4056 ke IN - pada STEP UP 5V. 


\subsection{Pengujian Pada Load Cell}

Pada pengujian Load Cell ini dilakukan dengan mengukur suatu obyek atau benda untuk mengetahui berat obyek atau benda tersebut, pada pengujian ini bertujuan untuk mengetahui load cell berfungsi dengan baik atau tidak. Berikut ini adalah hasil dari pengujian terhadap sensor load cell pada saat ada beban dan tidak ada beban infus.

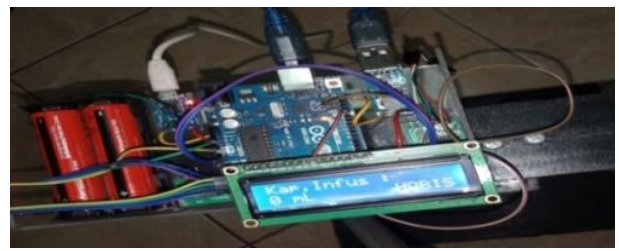

Gambar 15. Pengujian Load Cell Tanpa Beban Infus

Dari rangkaian di atas, menghubungkan antara analog 0 pada Arduino ke data di modul HX711, menghubungkan analog 1 pada Arduino ke SCK di modul HX711, menghubungkan VCC pada modul HX711 ke 5V di Arduino, menghubungkan GND pada Arduino ke GND di modul HX711, menghubungkan E+ pada modul HX711 ke kabel berwarna merah pada load cell, menghubungkan Epada modul HX711 ke kabel berwarna hitam pada load cell, menghubungkan A+ pada modul HX711 ke kabel berwarna hijau pada load cell, dan menghubungkan A- pada modul HX711 ke kabel berwarna putih pada load cell.

Berdasarkan Gambar 15 di atas dapat disimpulkan bahwa sensor Load Cell dapat bekerja dengan baik ketika tidak ada beban infus. Berikut ini pengujian Load Cell pada saat ada beban infus dengan tampilan LCD.

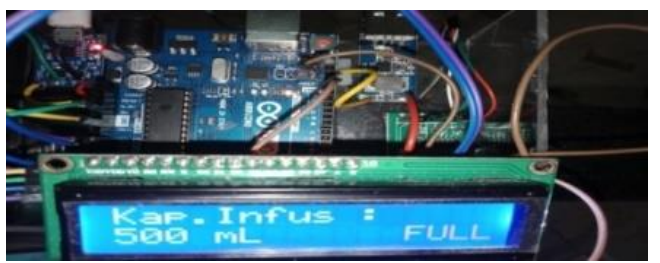

Gambar 16. Pengujian Sensor Load Cell Diberi Beban

\subsection{Pengujian Keseluruhan Alat}

Pengujian pada keseluruhan alat ini bertujuan agar mengetahui alat dapat bekerja dengan baik. Berikut adalah peralatan yang digunakan pada pembuatan alat dapat dilihat pada Tabel 2 .

Tabel 2. Peralatan alat

\begin{tabular}{cc}
\hline No & Peralatan \\
\hline 1 & Ardunino \\
2 & Sensor Load Cell \\
3 & Modul HX711 \\
4 & Modul 433MHz \\
5 & PowerBank \\
6 & Buzer dan LED \\
7 & Infus \\
8 & Kabel Jumper \\
9 & Laptop \\
10 & Kabel USB \\
11. & Software Arduino IDE \\
\hline
\end{tabular}


Berikut ini adalah hasil keseluruhan alat tanpa infus bisa dilihat pada Gambar 17 merupakan hasil rangkaian keseluruhan alat yang telah penulis rancang agar dapat bekerja dengan baik dalam memantau kondisi infus.

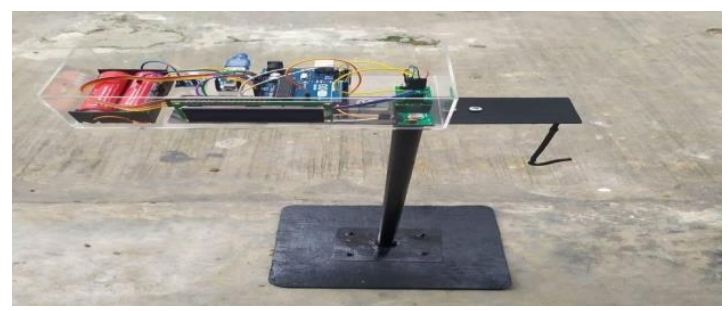

Gambar 17. Rangkaian Tanpa Infus

Pada gambar di atas dapat disimpulkan bahwa setelah melalui pengujian tiap-tiap alat berjalan dengan baik. Hasil dari keseluruhan alat menggunakan infus dapat dilihat pada Gambar 18 di bawah ini.

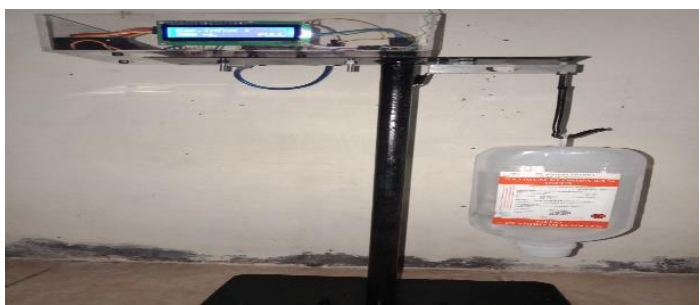

Gambar 18. Hasil Keseluruhan Alat

Pada gambar tersebut dapat disimpulkan bahwa alat yang telah dirancang oleh penulis dapat bekerja dengan baik sesuai yang di harapkan.

\section{KESIMPULAN DAN SARAN}

Berdasarkan hasil penelitian yang telah dilakukan didapat kesimpulan yaitu Rancang Bangun Alat Pemantau Infus Menggunakan Modul RF433MHZ Dan Sensor Load Cell Berbasis Arduino Uno telah berhasil dirancang dan dibuat dengan menggunakan mikrocontroller Arduino Uno dan Microcontroller Arduino Uno ATMega328p yang dikombinasikan dengan Modul RF $433 \mathrm{MHz}$ dan LCD dapat bekerja dengan baik sehingga perancangan pemantau infus otomatis bekerja sesuai dengan yang diharapkan.serta hasil pengujian sensor load cell berfungsi dengan baik dalam medeteksi berat dari infus. Sedangkang saran dari penelitian ini dapat dijadikan landasan pengembangan penelitian selanjutnya terutama bila ditambahkan sensor lainnya yang belum ada pada penelitian.

\section{DAFTAR PUSTAKA}

Adha, O. P., Muid, A., \& Brianorman, Y. (2015). Prototipe Sistem Buka Tutup Atap Jemuran Pakaian Menggunakan Mikrokontroler Atmega8. Jurnal Coding, Sistem Komputer Untan, 03(1), 20-29. Prototipe, Jemuran Otomatis, Mikrokontroler ATMega8.\%0A

Bernandus, Tarigan, J., \& Tanesib, J. L. (2019). Perancangan Sistem Pendeteksi Banjir Dengan Menggunakan Sensor HC-SR 04 Berbasis Arduino Uno. Jurnal Biotropikal Sains, 16(3), 1-9.

Desmitha, F., Kurniawan, W., Satya, U., Indonesia, N., \& Cell, S. L. (2019). RANCANG BANGUN SISTEM MONITORING VOLUME INFUS BERBASIS ARDUINO MEGA 2560 PADA RUMAH SAKIT UMUM. I, 81-92.

Hartanti, R. S. (2016). Analisis Konsentrasi Cairan Infus Terhadap Tegangan Pada Sensor Infus. JIPF (Jurnal Ilmu Pendidikan Fisika), 1(2), 45. https://doi.org/10.26737/jipf.v1i2.62

Iman, B., Dawolo, S., Safii, M., Gunawan, I., Parlina, I., \& Saputra, W. (2021). Rancang Bangun Alat 
Penghapus Papan Tulis Otomatis Berbasis Arduino Uno Menggunakan Sensor Suara. 1(1), 1120.

Rohman, F. S. N., Fikri, A. A., Fuad, A. N., Rohim, R., \& Firmansyah, R. (2017). Telemetri Flowmeter Menggunakan RF Modul 433MHz. JEEE-U (Journal of Electrical and Electronic Engineering-UMSIDA), 1(1), 8-14. https://doi.org/10.21070/jeee-u.v1i1.9

Rumopa, V. W., \& Luther Mappadang, J. (2015). Kontrol Penerangan Ruangan Menggunakan Sensor Suara ( Speech Recognition) Berbasis Android. Tugas Akhir.

Siswanto, D., \& Winardi, S. (2015). Jemuran Pakaian Otomatis Menggunakan Sensor Hujan. Narodroid, 1(2), 66-73. 


\section{Halaman Ini Dikosongkan}

